\title{
Rapid recolonisation of snapper Pagrus auratus: Sparidae within an offshore island marine reserve after implementation of no-take status
}

\author{
Christopher M. Denny ${ }^{1, *}$, Trevor J. Willis ${ }^{2}$, Russell C. Babcock ${ }^{3}$ \\ ${ }^{1}$ Leigh Marine Laboratory, PO Box 349, Warkworth, New Zealand \\ ${ }^{2}$ Laboratori Scienze Ambientali, Università di Bologna, Via Saint Alberto 163, 48100 Ravenna, Italy \\ ${ }^{3}$ CSIRO Marine Research Floreat, Private Bag No. 5, Wembley, Western Australia 6913, Australia
}

\begin{abstract}
This study reports the response of snapper Pagrus auratus to the establishment of notake status in a marine reserve around the Poor Knights Islands in northeastern New Zealand. The Poor Knights and 2 reference locations, Cape Brett and the Mokohinau Islands, were sampled biannually for $4 \mathrm{yr}$ using baited underwater video (BUV). Following the implementation of full marine reserve status at the Poor Knights in October 1998, snapper showed significant increases in abundance and biomass relative to fished control locations. This was particularly apparent for large snapper (>270 mm), whose numbers increased rapidly to levels 7.4 times higher in the final survey compared to the initial pre-reserve survey, and total snapper biomass increased by $818 \%$. There was no significant increase in the abundance, biomass or size of snapper at the reference locations over this time. There was a strong seasonal trend in snapper abundance, with higher numbers in autumn (March/April) compared to spring (September/October). The daily batch fecundity was 11 to 18 times higher at the Poor Knights compared to the reference locations. Once fishing ceased in previously partially protected areas, a rapid recovery of snapper ensued, suggesting that partial fishing regulations are ineffective for protecting targeted species. The speed of increase in snapper density resulted from the immigration of adult fish into the reserve, rather than from within-reserve recruitment.
\end{abstract}

KEY WORDS: Baited underwater video $\cdot$ Poor Knights $\cdot$ Fishing $\cdot$ Partial protection $\cdot$ Temperate reefs Temporal variation

Resale or republication not permitted without written consent of the publisher

\section{INTRODUCTION}

Marine reserves are becoming an increasingly popular concept for protecting fish species susceptible to exploitation from fishing, and the evidence that marine reserves increase the density, biomass and size of target species on reefs appears considerable (see reviews in Roberts \& Polunin 1991, Dugan \& Davis 1993, Rowley 1994, Attwood et al. 1997, Mosquera et al. 2000, Palumbi 2001, Halpern 2003). However, in a recent review, Russ (2002) concluded that the empirical evidence for positive marine reserve effects is more equivocal than other reviews have suggested, with a lack of any well designed, defini- tive experiments carried out at appropriate scales of time and space (also see Guidetti 2002, Willis et al. 2003b).

The lack of suitable data prior to the establishment of a marine reserve makes it difficult to quantify the rate of response to protection. However, where pre-reserve data are available, rapid rates of increase have been reported (White 1988, Russ \& Alcala 1996, Edgar \& Barrett 1999). For example, McClanahan \& KaundaArara (1996) found that lethrinids showed a 13.5-fold increase in biomass in the Mombasa National Park over $3 \mathrm{yr}$ following reserve establishment. In a recent meta-analysis, Halpern \& Warner (2002) noted that significant increases in density and biomass are 
attained in the first 1 to $3 \mathrm{yr}$ after protection. However, the strength of their meta-analysis is reduced by the heterogeneity of the sample, mixing well managed with poorly managed reserves, and partial with full protection (Gell \& Roberts 2003).

The Poor Knights Islands Marine Reserve, located in northeastern New Zealand, was established in 1981 with special fisheries regulations. Prior to 1 October 1998, when the Poor Knights was given no-take marine reserve status, it was effectively a partial marine reserve. Allowing certain forms of fishing in marine reserves or marine protected areas (MPAs) is a common scenario, and is often advocated by groups with direct fishing interests as a 'compromise' solution, allowing both protection and fishing. For example, Francour et al. (2001) found that amateur and commercial fishing was allowed in half the MPAs in the Mediterranean, and of the 100 MPAs in California, less than a quarter of $1 \%$ of their combined area is completely protected from fishing (McArdle 1997). Studies of the effects of fishing have indicated that relatively little fishing pressure is needed to cause significant reductions in the density of targeted species (Russ \& Alcala 1989, Jennings \& Polunin 1996). Despite this, the effectiveness of partial closures for either conservation or enhanced fishing has not been well evaluated (but see Francour 1994, Vacchi et al. 1998, Westera et al. 2003, Denny \& Babcock 2004).

This study examines the effects of full marine reserve protection on snapper Pagrus auratus (Bloch and Schneider 1801) populations at the Poor Knights, and compares temporal trends in snapper density with 2 reference locations, Cape Brett and the Mokohinau Islands. Snapper are the most abundant demersal predatory fish species in northeast New Zealand, and they support one of New Zealand's most valuable commercial and recreational fisheries. This species is a dominant predator, and is thought to have an impact on the structure and dynamics of coastal marine ecosystems in New Zealand (Babcock et al. 1999, Shears \& Babcock 2002, 2003). In this study, baited underwater video (BUV) was used to provide quantitative estimates of snapper abundance, biomass, size and egg production. This study provides a record of the rate of recolonisation of a key fish species, providing valuable insights into the mechanisms of fish recovery in marine reserves.

\section{MATERIALS AND METHODS}

Study sites. Three locations were surveyed in northeastern New Zealand: the Poor Knights Islands, Cape Brett and the Mokohinau Islands (Fig. 1). The Poor Knights Islands Marine Reserve was established in 1981 with special fisheries regulations. From 1981 to October 1998, all commercial fishing was prohibited. However, recreational fishers were able to use unweighted, single-hook lines, trolling and spearing to catch a permitted number of species within $95 \%$ of the reserve area (see Fig. 1 for protected areas). The 2 unprotected reference locations were selected to be as similar to the Poor Knights as possible in terms of hydrology and topography to minimise differences that may exist between the locations. However, as Underwood (1994) noted, it is impractical and unnecessary to choose locations with identical characteristics or abundances of the targeted species, provided sampling bias is avoided.

The initial survey at the Poor Knights was conducted in September 1998, prior to full marine reserve establishment in October. Surveys continued biannually in spring (September/October), and autumn (March/

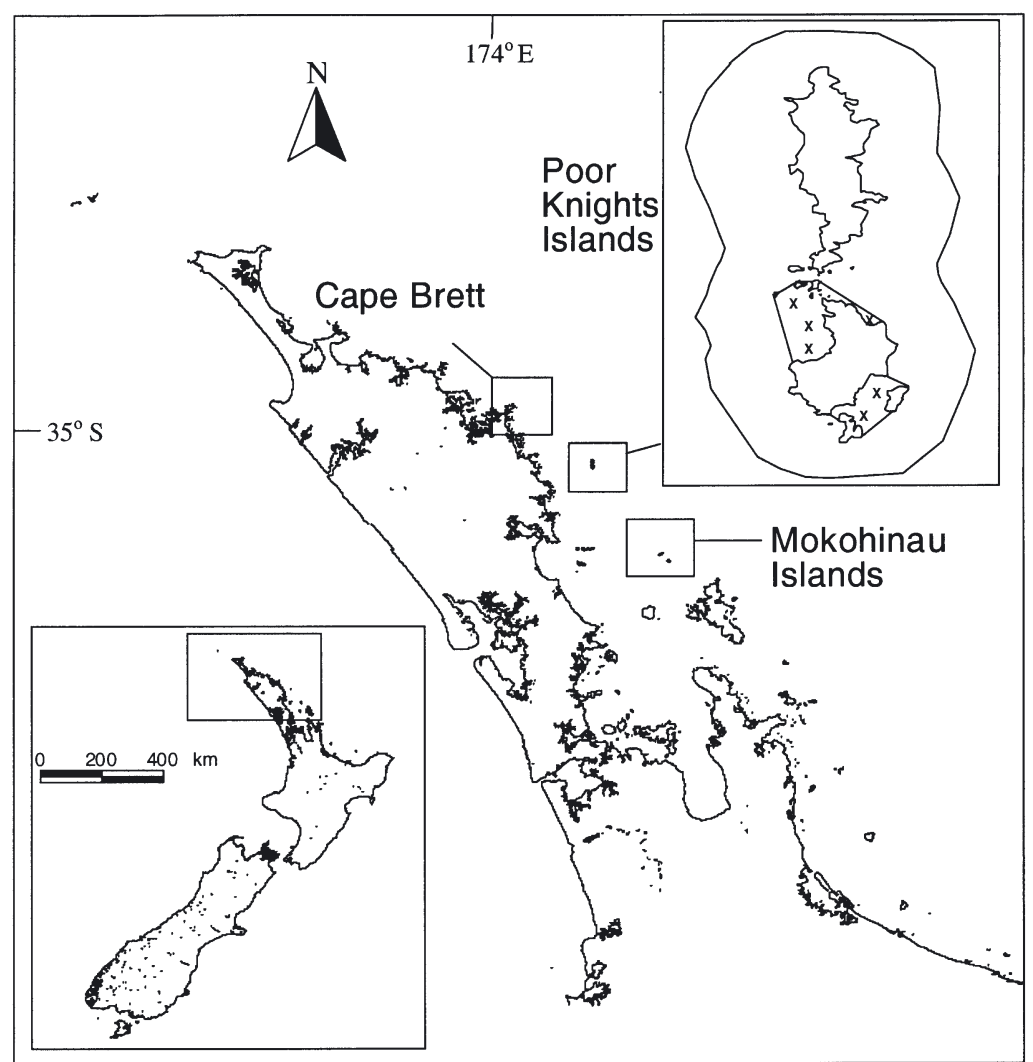

Fig. 1. Northern New Zealand, showing location of Cape Brett, the Poor Knights and Mokohinau Islands. Inset, upper right, of the Poor Knights shows reserve boundary (outer line) and areas closed to fishing prior to 1 October 1998 (marked with X) 
April) until September 2002. The 2 reference locations were surveyed biannually from September 1999 until September 2002. It would have been desirable to include the reference sites in the study from the beginning; however, this was not possible. Even so, the study still addresses whether trends in fish abundance differ between the Poor Knights from those at reference locations (Underwood 2000).

Baited underwater video (BUV). Use of the BUV technique (Willis \& Babcock 2000) allows sampling of carnivorous species that are not amenable to underwater visual census methods and can sample at depths greater than scuba divers can operate. The BUV system consists of a triangular stainless steel stand, with a Sony XC-777P high-resolution colour camera in a waterproof housing, positioned $1.25 \mathrm{~m}$ above a bait container with ca. $300 \mathrm{~g}$ of pilchard Sardinops neopilchardus. The BUV was deployed from the research vessel to depths of up to $50 \mathrm{~m}$. Each sequence was recorded for $30 \mathrm{~min}$ from the time the video assembly reached bottom. A $100 \mathrm{~m}$-long coaxial cable connected the underwater camera to a Sony GV-S50E video monitor and $8 \mathrm{~mm}$ recorder on the research vessel, enabling the operator to ensure the stand was upright and positioned over suitable substratum. Thirty replicate deployments were made at each location.

At the laboratory, $8 \mathrm{~mm}$ videotapes were copied to $16 \mathrm{~mm}$ VHS tapes for analysis and archiving. Videotapes were played back with a real-time counter, and the maximum number of snapper observed during each minute was recorded to determine the maximum number of snapper in each replicate. Recording the maximum number has been previously shown to provide the best estimates of relative snapper density (Willis \& Babcock 2000). The lengths of snapper were obtained by digitising video images using the Sigmascan, image analysis system. Measurements were taken only of those fish present when the count of the maximum number of fish of a given species in a sequence was made. This means that some fish moving in and out of the field of view may not have been measured, and the method avoids repeated measurements of the same individuals. This approach is likely to result in more conservative abundance estimates in high-density areas than low-density areas; differences between sites are therefore likely to be conservative.

To calculate the biomass (weight: $W$ ) of snapper, lengths (standard length: $\mathrm{SL}, \mathrm{mm}$ ) were converted to mass ( $g$ ) using the formula:

$$
W=0.00007194 \times \mathrm{SL}^{2.793} \quad \text { (Taylor \& Willis 1998) }
$$

To determine the difference in potential reproductive output between the reserve and reference locations, snapper fecundity (expressed as daily batch fecundity: $F$ ) was estimated using the formula:

$$
F=73 \times 9 \times W-7793 \quad \text { (Zeldis \& Francis 1998) }
$$

These authors found the significance of the relationship between fish weight and batch fecundity was $\mathrm{r}^{2}=$ 0.72. (See Willis et al. 2003a for a detailed description of this methodology.)

Data analysis. BUV data are counts and therefore do not satisfy the assumptions of normality and homogeneity of variance that are required by ANOVA. Accordingly, the data were analysed using a log-linear model (assuming a Poisson distribution) to obtain unbiased estimates of the relative abundance of snapper and determine the ratio of snapper change. The minimum legal size (MLS) of $270 \mathrm{~mm}$ SL is the smallest size at which this species can be legally retained if caught by recreational fishers. Therefore, changes in the density of sublegal $(<270 \mathrm{~mm} \mathrm{SL})$ and legal $(>270 \mathrm{~mm})$ snapper present between spring surveys were also determined. 'Survey', 'Location' and 'Season' were the factors used in the model. Changes in the biomass and the daily batch fecundity of snapper were examined using the model described above.

The initial survey at the Poor Knights was conducted when areas had either full or partial protection (see Fig. 1). This allowed an assessment of the effectiveness of different protection regimes. The number of snapper per BUV from both fully protected areas and areas with partial protection, using only the spring 1998 survey, were analysed using a log-linear model, with 'Status' as the factor in the main model.

To test whether the regression slope of legal snapper density versus time (spring data only) was significantly different between locations, the Graphpad Prism ${ }^{\odot}$ (V4) computer program was used. This program compares regression lines (Zar 1984) and is equivalent to ANCOVA.

Changes in the size of snapper were analysed using pairwise Kolmogorov-Smirnov tests and ANOVA. Data were tested for normality using the Shapiro-Wilks test and examination of residual plots. The observed differences between the mean sizes were tested for statistical significance using Tukey's studentized range test.

\section{RESULTS}

Total snapper density at the Poor Knights Islands increased significantly after complete protection, so that after $4 \mathrm{yr}$ snapper were 6.9 times more abundant (lower $95 \%$ confidence limit, CL, of 3.6; upper $95 \%$ CL of 13.2) $\left(\chi_{4,147}^{2}=59.5, \mathrm{p}<0.01\right)$. When legal snapper $(>270 \mathrm{~mm}$ ) were examined at the Poor Knights (fish over this size are vulnerable to fishing), overall densities had increased by 7.4 times (95\% CL 3.8, 14.5) since the initial survey $\left(\chi_{4,147}^{2}=71.1, p<0.01\right)$ (Fig. 2a). Changes in the density of legal snapper between 


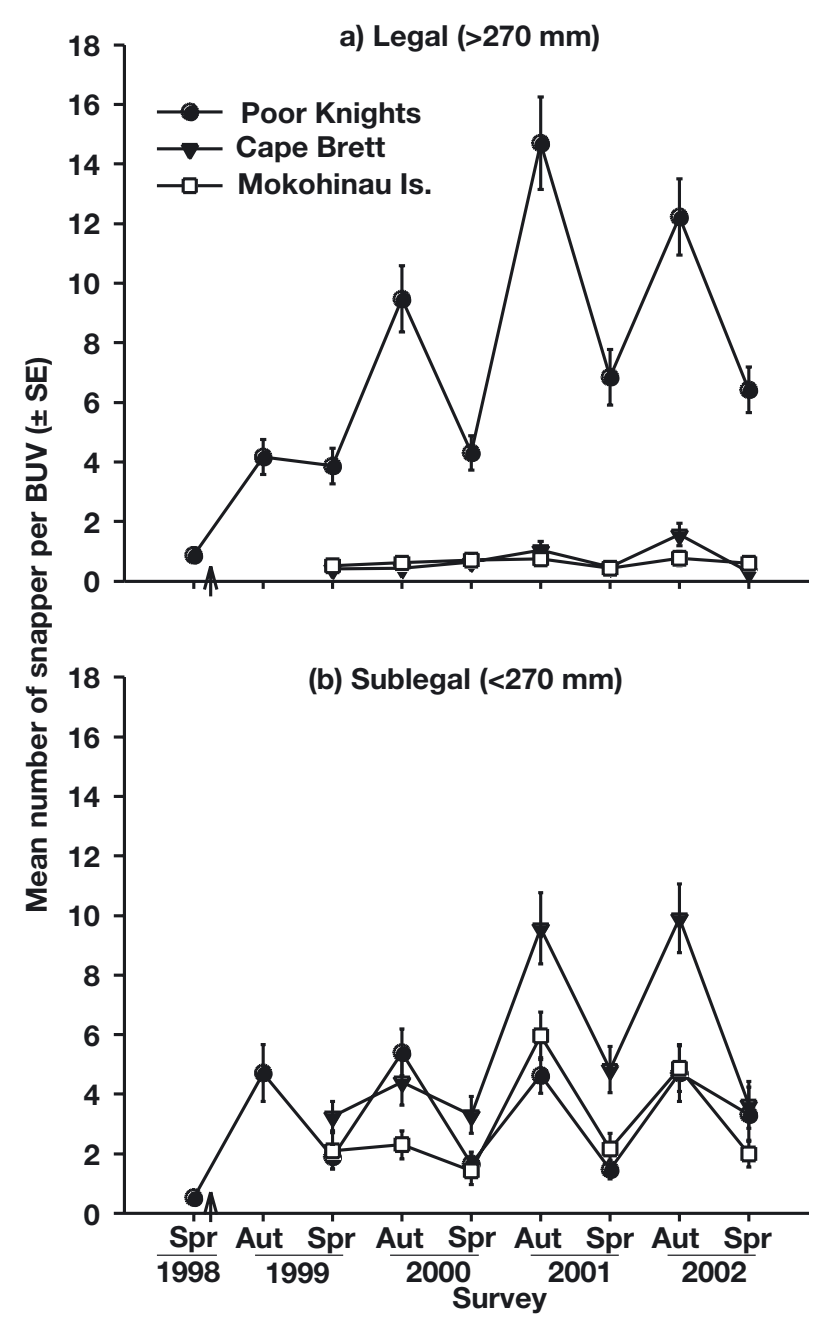

Fig. 2. Pagrus auratus. Mean number of (a) legal size snapper ( $>270 \mathrm{~mm})$, (b) sublegal snapper $(<270 \mathrm{~mm})$ per baited underwater video (BUV) $( \pm$ SE) at the Poor Knights from spring 1998 to autumn 2002 and at Cape Brett and Mokohinau Islands from spring 1999 to spring 2002. Spr and Aut: spring and autumn, respectively. Arrow on $x$-axis indicates establishment of no-take reserve status

spring surveys were examined, as fish present during spring are likely to be residents (Willis et al. 2001). Numbers increased significantly by 4.5 times (95\% CL $2.3,8.5)$ in the spring surveys between 1998 and 1999 $\left(\chi_{1,57}^{2}=26.21, \mathrm{p}<0.01\right)$ and by 1.59 times between 2000 and $2001\left(\chi_{1,60}^{2}=5.92, p=0.015\right)$. There was no significant change in the density of legal snapper at the reference locations (Fig. 2a). The density of legal snapper at the Poor Knights was 22.1 and 10.8 times higher than at Cape Brett and the Mokohinau Islands (95\% CL 8.8, 55.6 and 5.1, 23.1, respectively). The regression slope of legal snapper density versus time (using spring data) was significantly different between the Poor Knights and both the Mokohinau Islands (ANCOVA, $F=10.96, \mathrm{p}=0.02)$ and Cape Brett $(F=$
11.64, $\mathrm{p}=0.019)$. There was no statistically significant difference in the regression slope between reference locations.

The density of sublegal snapper increased significantly at the Poor Knights by 6.2 times (95\% CL 2.5, 15.8) since the initial survey $\left(\chi^{2}{ }_{4,147}=22.9\right.$, p $\left.<0.01\right)$ (Fig. 2b). The overall density of sublegal fish did not differ significantly between locations but did tend to be higher at Cape Brett than at either island location. Moreover, the density of sublegal snapper appears to be variable, with Cape Brett varying more than the island locations (Fig. 2b).

There was a significant difference in snapper density between autumn and spring at all 3 locations $\left(\chi_{1,701}^{2}=\right.$ 129.36, p < 0.01), a trend apparent for both legal and sublegal fish (Fig. 2). The mean number of snapper was 2.3 times $(95 \%$ CL 1.9, 2.6) higher in autumn compared to spring.

The relative density of legal snapper was compared between areas with full and partial protection in Spring 1998 (prior to full no-take status). There was no statistically significant difference in the density of snapper between the fully and partially protected areas. In fact, the starting densities were virtually identical and both increased only after full reserve protection was given to the entire area.

There was an increase in the number of larger snapper at the Poor Knights, with the vast majority of fish in the later surveys being over the minimum legal size (Fig. 3). In contrast, there was no change in the size of snapper at the Mokohinau Islands (mean range between 215 and $258 \mathrm{~mm}$ ) or Cape Brett, where the highest numbers of small fish were consistently recorded (mean range between 200 and $221 \mathrm{~mm}$ ). Tukey's test found that the mean size of snapper was always significantly larger at the Poor Knights compared to the reference locations, and snapper at the Mokohinau Islands were usually significantly larger than at Cape Brett (Table 1). Large snapper (>400 mm) have become increasingly common at the Poor Knights, whereas at the reference locations, these large fish are almost never recorded (Fig. 3). There was no significant difference in the size of snapper between seasons at the Poor Knights and Cape Brett. However, snapper were significantly larger in spring at the Mokohinau Islands compared to the autumn surveys (ANOVA, $F_{1,731}=35.87, \mathrm{p}<0.01$ ), due to low numbers of sublegal fish in spring (Fig. 3).

The mean snapper biomass per BUV deployment increased significantly by $818 \%$ at the Poor Knights $\left(\chi^{2}{ }_{8,2548}=66.8, \mathrm{p}<0.01\right)$ from $771 \mathrm{~g}( \pm 305 \mathrm{SD})$ in the initial survey to $6310 \mathrm{~g}( \pm 552)$ in the final survey. There was no significant increase in biomass at the reference locations. In fact, snapper biomass for the final surveys at the reference locations were very similar to the 


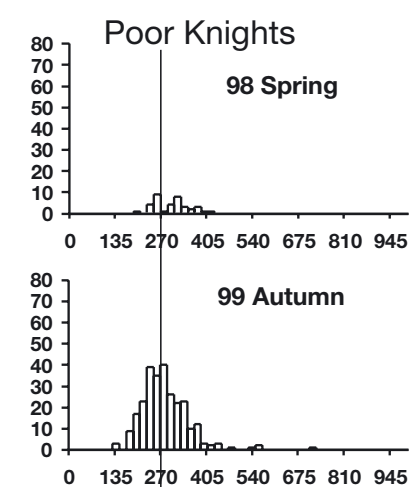

Mokohinau Islands

Cape Brett
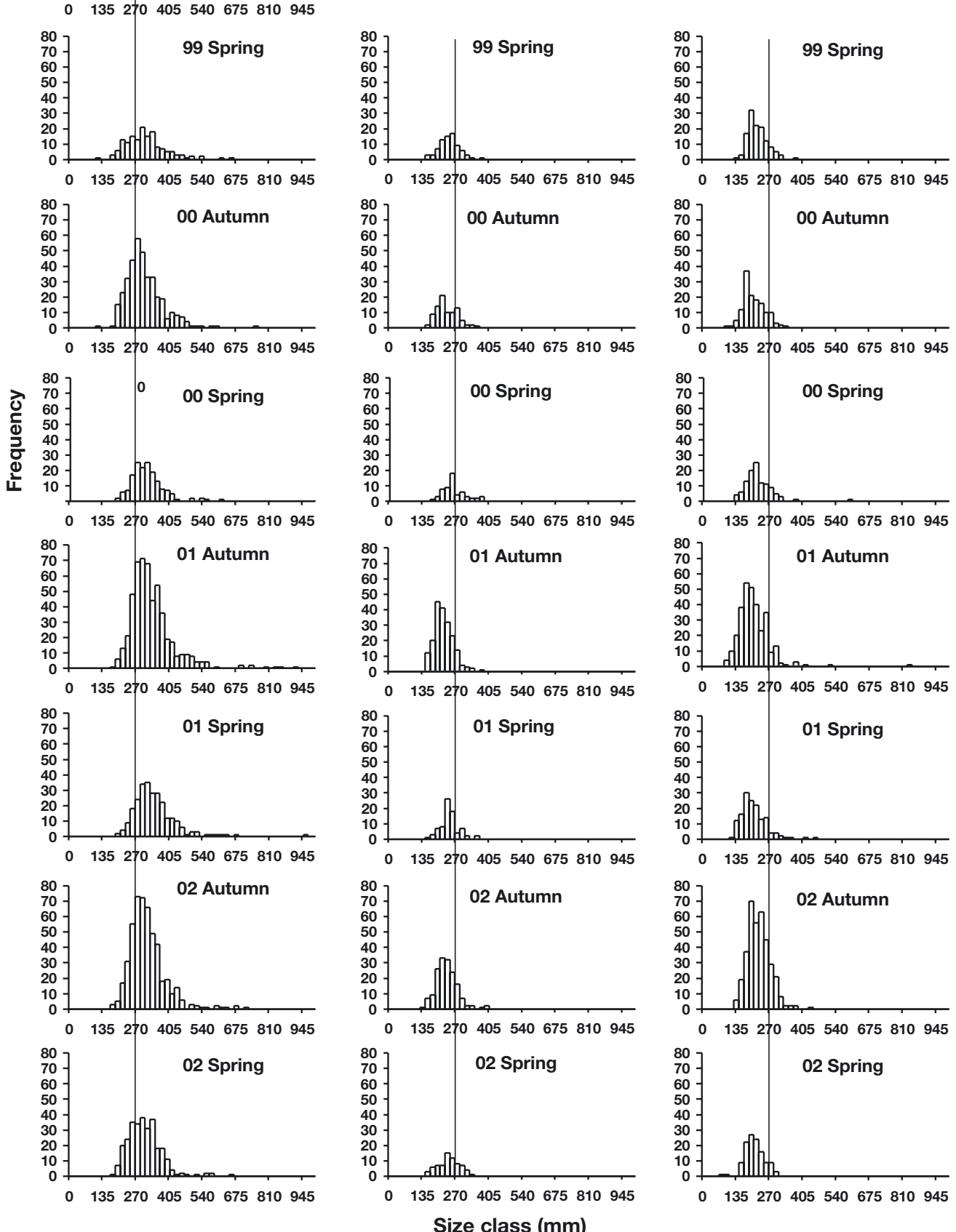

Fig. 3. Pagrus auratus. Size frequency (mm) of snapper at the Poor Knights from spring 1998 to spring 2002 and at Cape Brett and Mokohinau Islands from spring 1999 to spring 2002. Vertical line indicates the minimum legal size $(270 \mathrm{~mm})$ 
Table 1. Pagrus auratus. Tukey's studentized range (HSD) test for snapper size differences (mm) between locations with $95 \%$ confidence limits (CL). ${ }^{*} \mathrm{p}<0.05$. PKIMR: Poor Knights Islands Marine Reserve

\begin{tabular}{|c|c|c|c|c|c|c|}
\hline \multirow[b]{2}{*}{ Survey } & \multicolumn{2}{|c|}{ PKIMR-Mokohinau Island } & \multicolumn{2}{|c|}{ PKIMR-Cape Brett } & \multicolumn{2}{|c|}{ Mokohinau Island-Cape Brett } \\
\hline & $\begin{array}{c}\text { Difference } \\
\text { between } \\
\text { means }\end{array}$ & $95 \%$ CL & $\begin{array}{c}\text { Difference } \\
\text { between } \\
\text { means }\end{array}$ & $95 \% \mathrm{CL}$ & $\begin{array}{c}\text { Difference } \\
\text { between } \\
\text { means }\end{array}$ & $95 \%$ CL \\
\hline 1999 spring & $67.2^{*}$ & $46.6-87.8$ & $88.1^{*}$ & $70.3-106.0$ & 20.9 & $-0.5-42.3$ \\
\hline 2000 autumn & $69.5^{*}$ & $51.8-87.1$ & $97.0^{*}$ & $82.0-111.9$ & $27.5^{*}$ & $7.1-47.9$ \\
\hline 2000 spring & $52.1^{*}$ & $30.3-73.9$ & $91.4^{*}$ & $73.7-109.1$ & $39.3^{*}$ & $16.2-62.5$ \\
\hline 2001 autumn & $112.4^{*}$ & $97.5-127.3$ & $127.8^{*}$ & $115.0-140.7$ & $15.4^{*}$ & $-0.9-31.7$ \\
\hline 2001 spring & $99.1^{*}$ & $77.7-120.5$ & $135.6^{*}$ & $118.5-152.7$ & $36.5^{*}$ & $13.4-59.7$ \\
\hline 2002 autumn & $83.2^{*}$ & $70.6-95.8$ & $88.7^{*}$ & $79.0-98.3$ & 5.4 & $-7.7-18.6$ \\
\hline 2002 spring & $63.4^{*}$ & $45.0-81.9$ & $94.4^{*}$ & $79.4-109.4$ & $31.0^{*}$ & $10.2-51.8$ \\
\hline
\end{tabular}

initial Poor Knights survey; $747 \mathrm{~g}( \pm 158)$ at the Mokohinau Islands and $878( \pm 114)$ at Cape Brett.

The daily batch fecundity of snapper was similar between the Poor Knights and the reference locations in the initial surveys. However, when the final surveys were compared, daily egg production at the Poor Knights was $18.7( \pm 2.3 \mathrm{SE})$ and $11.6( \pm 1.8)$ times higher than at Cape Brett and the Mokohinau Islands, respectively $\left(\chi_{2,3042}^{2}=138.78, p<0.01\right)$. In addition, daily egg production significantly increased $8.5( \pm 0.7)$ times at the Poor Knights between the initial and final survey $(\mathrm{p}<0.01)$.

\section{DISCUSSION}

Following the implementation of full marine reserve status at the Poor Knights in 1998, snapper showed significant increases relative to reference locations in abundance and biomass over time. The magnitude of increase in snapper in the Poor Knights Reserve is consistent with many other studies that found a significant increase in the density and/or biomass of large predatory fish following no-take status (White 1988, McClanahan \& Kaunda-Arara 1996, Russ \& Alcala 1996, Edgar \& Barrett 1999). The increase in snapper abundance following protection was surprisingly rapid: some time-lag period might be expected when fish populations are recovering from previous heavy fishing pressure (Polunin \& Roberts 1993). For example, Russ \& Alcala (1996) found a slow increase in fish biomass in the first 3 to $5 \mathrm{yr}$ of protection, followed by a more rapid increase in the next $4 \mathrm{yr}$. This time lag might be particularly noticeable where recovery is dependent on recruitment. Recovery rates are likely to be variable, and can depend on other factors such as species, location and level of exploitation.

The rapid recovery of snapper at the Poor Knights, particularly in the first year, is due to the immigration of large fish, rather than juvenile recruitment. These large fish arrive at the Poor Knights because of regular seasonal onshore and offshore movements (Willis et al. 2003a). A proportion of these fish take up residence on the reefs, where they may remain in home range areas of less than $300 \mathrm{~m}$ diameter (Parsons et al. 2003) for more than 4 yr (Willis et al. 2001). This idea has been visited by Willis et al. (2003a), and is well supported by data at the Poor Knights where fish present had a modal size of $410 \mathrm{~mm}$ SL by autumn 2000. These fish would have be approximately $14 \mathrm{yr}$ old (Millar et al. 1999) so could not have grown to this size in the $2 \mathrm{yr}$ after full protection. The variable densities of sublegal snapper, related to sea surface temperature and seasonal deviations in the EAC (Francis 1993), probably accounts for the initial increase in sublegal snapper at the Poor Knights, rather than an effect of the marine reserve itself.

Seasonal variation in snapper abundance is consistent with other studies on snapper in New Zealand (Willis et al. 2003a). This seasonal trend is a wellknown phenomenon among reef fish, with many species undertaking relatively extensive seasonal migrations that can range from a few metres up to several kilometres (Hobson 1973, Hyndes et al. 1999). The most likely reason for the seasonal variation in snapper is an onshore migration to shallower waters in summer to spawn (Crossland 1977, Robertson 1983) and a return to deeper offshore areas in winter. Alternatively, the observed temporal variation may be explained by feeding migrations (Ogden \& Buckman 1973). Despite the commercial importance of snapper, their behaviour and ecology at small spatial scales is still poorly known. The investigation of snapper movements, home range sizes and spatial patterns of resource use using radio telemetry is currently underway (Egli \& Babcock 2002).

Large snapper are capable of producing more eggs per unit body mass than smaller fish (Zeldis \& Francis 1998). Therefore, the number of large snapper and their high potential egg production means that the Poor Knights could act as a source of eggs and/or larvae, which may eventually settle outside the reserve as well 
as within it (Jones et al. 1999, Swearer et al. 1999). Potential egg production at the Poor Knights, 18.7 times higher than the coast, is very similar to the values found by Willis et al. (2003a). If we assume that potential egg production is 18 times higher in the Poor Knights compared to the adjacent coast, then the Poor Knights with a coastline of $20.1 \mathrm{~km}$ represents egg production equal to $362 \mathrm{~km}$ of 'fished' coastline. Thus, relatively small no-take reserves have the potential to sustain recruitment in much larger portions of the coast.

This study provides evidence that partial fishing regulations are ineffective at protecting targeted species, at least where recreational and commercial fishers both target the same species. This presents a powerful argument against the widely held view that recreational fishing cannot affect fish populations. There was no build-up of snapper populations at the Poor Knights following the creation of the 'marine reserve' in 1981 that allowed partial harvest within $95 \%$ of the reserve. This was most likely due to recreational fishing pressure, as even limited fishing effort would maintain fish biomass at low levels (Jennings \& Polunin 1996). Similar results were found at the Mimiwhangata Marine Park (identical fishing restrictions as were present at the Poor Knights prior to full reserve status) where no difference was found in snapper numbers between protected and adjacent unprotected areas (Denny \& Babcock 2004). Paradoxically, fishing pressure may have been higher in the 1980s and 1990s at the Poor Knights than at the Mokohinau Islands or the adjacent coast. In the absence of commercial fishing, there may have been a perception that fish were larger and more plentiful in the reserve area. Thus, 'marine reserve' status and fishing gear restrictions at the Poor Knights may have had exactly the opposite effect to that intended.

There was no difference in relative snapper density between the small, fully protected areas and partially protected areas, prior to the islands receiving no-take status. The exclusion zones may have been too small to effectively protect snapper from fishing pressure: tagging studies suggest that some snapper move over moderate distances (>100 km) (Paul 1967), although Parsons et al. (2003) found some snapper to have considerable site fidelity (home ranges not exceeding $650 \mathrm{~m}$ ). This finding is important because recent metaanalyses (e.g. Mosquera et al. 2000, Halpern 2003) have made general statements about the uniformity of response to protection from fishing, regardless of reserve size. Their conclusions are not universal, and will not apply to all species or all locations. There may also have been considerable edge effects because of the small size and configuration of the closed areas, resulting in fish being caught outside the areas. Edge effects have been demonstrated at the Leigh Marine Reserve
(Willis et al. 2000), where recreational fishers commonly anchor and fish on the reserve boundary.

This study has clearly demonstrated the effectiveness of no-take status at the Poor Knights Islands Marine Reserve for increasing the density of a targeted fish species. The increase in density of snapper to the complete cessation of fishing suggests that partial protection is ineffective as a conservation tool for heavily targeted species. It is clear that the rate of recolonisation of fishes to protected areas is likely to be at least partially dependent on the natural abundance of fish found in the locality, as well as local habitat quality. This can be seen in the varying reserve:non-reserve ratios of legal snapper at no-take reserves on the nearby mainland coast, which range from 8.8:1 to 16.5:1 (Willis et al. 2003a). There has been no observed recovery of snapper in reserves in southern New Zealand, e.g. Tonga Island (R. Davidson pers. comm.). That such large location-specific differences in the rate and magnitude of response to reserve protection can occur within a heavily exploited species complicates efforts to make general predictions about reserve effects, even for single species. It follows that assemblage-level predictions are even more difficult to make with accuracy. Small-scale habitat characteristics may be effective predictors in some cases, but reserves should not be regarded as independent of processes occurring in the surrounding, exploited waters.

Acknowledgements. We wish to thank P. Bendle, B. Doak, M. Birch and G. Murman for skippering their various vessels in sometimes suspect weather conditions, and the many people who helped control the BUV. These are D. Egli, D. Feary, T. Gee, T. Langlois, G. Nesbitt, D. Parsons, A. Rapson, L. Richards, P. Ross, J. Saunders, N. Shears, E. Skipworth, T. Smith, S. Van Dijken, J. Walker, C. Williams and J. Williams. Also thanks to A. Salomon and N. Tolimieri and 2 anonymous reviewers for constructive comments and the Department of Conservation for funding this study.

\section{LITERATURE CITED}

Attwood CG, Mann BQ, Beaumont J, Harris JM (1997) Review of the state of marine protected areas in South Africa. S Afr J Mar Sci 18:341-367

Babcock RC, Kelly S, Shears NT, Walker JW, Willis TJ (1999) Changes in community structure in temperate marine reserves. Mar Ecol Prog Ser 189:125-134

Crossland J (1977) Seasonal reproductive cycle of snapper Chrysophrys auratus (Forster) in the Hauraki Gulf. NZ J Mar Freshw Res 11:37-60

Denny CM, Babcock RC (2004) Do partial marine reserves protect reef fish assemblages? Biol Conserv 116:119-129

Dugan JE, Davis GE (1993) Applications of marine refugia to coastal fisheries management. Can J Fish Aquat Sci 50: 2029-2042

Edgar GJ, Barrett NS (1999) Effects of the declaration of marine reserves on Tasmanian reef fishes, invertebrates and plants. J Exp Mar Biol Ecol 242:107-144 
Egli DP, Babcock RC (2002) Optimising marine reserve design in New Zealand-Part 1: behavioural data for individual based models. Report to the Department of Conservation, Northland Conservancy, Auckland

Francis MP (1993) Does water temperature determine year class strength in New Zealand snapper (Pagrus auratus, Sparidae). Fish Oceanogr 2:65-72

Francour P (1994) Pluriannual analysis of the reserve effect on ichthyofauna in the Scandola natural reserve (Corsica, Northwestern Mediterranean). Oceanol Acta 17:309-317

Francour P, Harmelin JG, Pollard D, Sartoretto S (2001) A review of marine protected areas in the northwestern Mediterranean region: siting, usage, zonation and management. Aquat Conserv: Mar Freshw Ecosyst 11:155-188

Gell FR, Roberts CM (2003) The fishery effects of marine reserves and fishery closures. World Wildlife Fund, Washington, DC

Guidetti P (2002) The importance of experimental design in detecting the effects of protection measures on fish in Mediterranean MPAs. Aquat Conserv: Mar Freshw Ecosyst 12: $619-634$

Halpern BS (2003) The impact of marine reserves: do reserves work and does reserve size matter? Ecol Appl 13:S117-S137

Halpern BS, Warner RR (2002) Marine reserves have rapid and lasting effects. Ecol Lett 5:361-366

Hobson ES (1973) Diel feeding migrations in tropical reef fishes. Helgol Wiss Meeresunters 24:361-370

Hyndes GA, Platell ME, Potter IC, Lenanton RCJ (1999) Does the composition of the demersal fish assemblages in temperate coastal waters change with depth and undergo consistent seasonal changes? Mar Biol 134:335-352

Jennings S, Polunin NVC (1996) Effects of fishing effort and catch rate upon the structure and biomass of Fijian reef fish communities. J Appl Ecol 33:400-412

Jones GP, Milicich MJ, Emslie MJ, Lunow C (1999) Selfrecruitment in a coral reef fish population. Nature 402: 802-804

McArdle DA (1997) California marine protected areas. California Sea Grant Publication, University of California, San Diego, CA

McClanahan TR, Kaunda-Arara B (1996) Fishery recovery in a coral-reef marine park and its effect on the adjacent fishery. Conserv Biol 10:1187-1199

Millar RB, McArdle BH, Harley SJ (1999) Modelling the size of snapper (Pagrus auratus) using temperature-modified growth curves. Can J Fish Aquat Sci 56:1278-1284

Mosquera I, Cote IM, Jennings S, Reynolds JD (2000) Conservation benefits of marine reserves for fish populations. Anim Conserv 4:321-332

Ogden JC, Buckman NS (1973) Movements, foraging groups, and diurnal migrations of the striped parrotfish Scarus croicensis Bloch (Scaridae). Ecology 54:589-596

Palumbi SR (2001) The ecology of marine protected areas. In: Bertness MD, Gaines SD, Hay ME (eds) Marine community ecology. Sinauer Associates, Sunderland, MA, p 509-530

Parsons DM, Babcock RC, Hankin RKS, Willis TJ, Aitken JP, O'Dor RK, Jackson GD (2003) Snapper Pagrus auratus (Sparidae) home range dynamics: acoustic tagging studies in a marine reserve. Mar Ecol Prog Ser 262:253-265

Paul LJ (1967) An evaluation of tagging experiments on the New Zealand snapper, Chrysophrys auratus (Forster), during the period 1952 to 1963. NZ J Mar Freshw Res 1: 455-463

Polunin NVC, Roberts CM (1993) Greater biomass and value of target coral-reef fishes in two small Caribbean marine reserves. Mar Ecol Prog Ser 100:167-176

Roberts CM, Polunin NVC (1991) Are marine reserves effec- tive in management of reef fisheries? Rev Fish Biol Fish 1:65-91

Robertson DR (1983) On the spawning behaviour and spawning cycles of eight surgeonfishes (Acanthuridae) from the Indo-Pacific. Environ Biol Fish 9:193-223

Rowley RJ (1994) Marine reserves in fisheries management. Aquat Conserv: Mar Freshw Ecosyst 4:233-254

Russ GR (2002) Yet another review of marine reserves as reef fishery management tools. In: Sale PF (ed) Coral Reef Fishes. Dynamics and diversity in a complex ecosystem. Academic Press, San Diego, p 421-443

Russ GR, Alcala AC (1989) Effects of intense fishing pressure on an assemblage of coral reef fishes. Mar Ecol Prog Ser 56:13-27

Russ GR, Alcala AC (1996) Marine reserves: rates and patterns of recovery and decline of large predatory fish. Ecol Appl 6:947-961

Shears NT, Babcock RC (2002) Marine reserves demonstrate top-down control of community structure on temperate reefs. Oecologia 132:131-142

Shears NT, Babcock RC (2003) Continuing trophic cascade effects after 25 years of no-take marine reserve protection. Mar Ecol Prog Ser 246:1-16

Swearer SE, Caselle JE, Lea DW, Warner RR (1999) Larval retention and recruitment in an island population of a coral-reef fish. Nature 402:799-802

Taylor RB, Willis TJ (1998) Relationships amongst length, weight and growth of north-eastern New Zealand reef fishes. Mar Freshw Res 49:255-260

Underwood AJ (1994) On beyond BACI: Sampling designs that might reliably detect environmental disturbances. Ecol Appl 4:3-15

Underwood AJ (2000) Importance of experimental design in detecting and measuring stresses in marine populations. J Aquat Ecosyst Stress Rec 7:3-24

Vacchi M, Bussotti S, Guidetti P, La Mesa G (1998) Study of the coastal fish assemblage in the marine reserve of the Ustica Island (southern Tyrrhenian Sea). Ital J Zool 65:281-286

Westera M, Lavery P, Hyndes G (2003) Differences in recreationally targeted fishes between protected and fished areas of a coral reef marine park. J Exp Mar Biol Ecol 294: $145-168$

White AT (1988) The effect of community-managed marine reserves in the Philippines on their associated coral reef fish populations. Asian Fish Sci 2:27-41

Willis TJ, Babcock RC (2000) A baited underwater video system for the determination of relative density of carnivorous reef fish. Mar Freshw Res 51:755-763

Willis TJ, Millar RB, Babcock RC (2000) Detection of spatial variability in relative density of fishes: comparison of visual census, angling, and baited underwater video. Mar Ecol Prog Ser 198:249-260

Willis TJ, Parsons DM, Babcock RC (2001) Evidence for longterm site fidelity of snapper (Pagrus auratus) within a marine reserve. NZ J Mar Freshw Res 35:581-590

Willis TJ, Millar RB, Babcock RC (2003a) Protection of exploited fishes in temperate regions: high density and biomass of snapper Pagrus auratus (Sparidae) in northern New Zealand marine reserves. J Appl Ecol 40:214-227

Willis TJ, Millar RB, Babcock RC, Tolimieri N (2003b) Burdens of evidence and the benefits of marine reserves: putting Descartes before des horse? Environ Conserv 30:97-103

Zar A (1984) Biostatistical analysis, Vol 1. Prentice-Hall, Englewood Cliffs, NJ

Zeldis JR, Francis MP (1998) A daily egg production method estimate of snapper biomass in the Hauraki Gulf, New Zealand. ICES J Mar Sci 55:522-534 